\title{
Teacher Challenges and Solutions in Teaching EFL Students
}

\author{
Ida Bagus Yoga Buana Surya Putra \\ Ganesha University of Education, Indonesia \\ idabagusyogabuanasuryaputra18@gmail.com
}

\begin{abstract}
The present study was aimed at identifying the EFL teacher challenges in teaching English, EFL learners' problems in the classroom from teacher's perspective, and the EFL teacher's solutions for the problems exist in the classroom activity at SMK Negeri 1 Gianyar. A qualitative method was used to identify an EFL teacher challenges and solutions in teaching English. An interview was done through Google Form and WhatsApp chat with the participant. The results revealed that there are two main challenges faced by the teacher and four main challenges faced by the students based on the teacher's perspective. Additionally, the study also revealed the teacher's solutions for the challenges appeared during the English teaching process. Further, it is suggested for the teacher to use jigsaw strategy in teaching that will make the students take an important part in teamwork instead of without doing nothing in a group activity.
\end{abstract}

Keywords: learning challenges, teaching challenges, teaching solutions

\section{INTRODUCTION}

English is one of the international language that taught to Indonesian students. So, what did you feel when you got English lesson firstly in your school? Every student will say that they get difficulty and less of motivation when learning English. There are so many challenges for the teacher as the instructor in teaching English and students as the learners in learning English.

Teacher as the instructor take important roles in guiding the learners, especially in teaching English to the EFL learners. There will be some challenges for teacher when teaching in the classroom and it can happen in many aspects, take for example if the class is naughty, teacher will be difficult to control the students. So that he/she should have a solution to make the classroom condition back to normal situation.

Students as the learners also have their problems when learning English. Learning English as a second or foreign language is a complex process that involves numerous aspects and areas. Every English language learner faces a unique set of challenges when it comes to language acquisition. However, the capacity of the learners plays an important role; it is determined by the learners' intelligence and the amount of effort they put forth in taking steps to overcome the obstacles (Mohammed, 2018).

Several studies reported the problems in teaching English as a Foreign Language in Indonesian context. Firstly, Mumary Songbatumis (2017) has reported that lack of training, language skill problem, lack of teaching method, lack of IT skills, and lack of professional development are the teachers' challenges in teaching English. Besides that, the students are also having some challenges in 
learning English such as lack of concentration during the learning process, speaking skill problem, lack of attitude, boredom, and lack of vocabulary mastery. Secondly, Marcellino (2008) also has reported the challenges in teaching English. Students' language proficiency is affected by their cultures and bad language environment. In terms of the teachers' challenges in teaching English, preparations and performance are the main problems for the teachers in teaching English. Lastly, Zaim (2017) has identified the teachers' ability in implementing the steps pf scientific approach in teaching English. The result has reported that from five steps of scientific approach namely observing, questioning, experimenting, associating, and communicating. The teachers found it difficult to implement observing and questioning phase.

From the existing studies that showed various challenges in teaching English, therefore, this study is conducted in order to identify the EFL teacher challenges in teaching English, EFL learners' problems in classroom, and the teacher's solutions for the problems exist in the classroom activity. The data were collected by doing an interview to an English teacher. Specifically, the writer used Google Form and WhatsApp chat in collecting the data. There is a reason why the writer used those two application in collecting the data, that because the effectiveness of doing an interview without face to face meeting with the interviewees. So, the teacher can easily fill the form that given by the researcher and it do not disturb the teacher's time.

\section{METHOD}

Design

Regarding the aims of the present study, qualitative research is a design used in this research. This design enables the researcher to gain rich information through the subjects' experiences. As stated by Nassaji (2015, p. 129), "Qualitative research is holistic and often involves a rich collection of data from various sources to gain a deeper understanding of individual participants, including their opinions, perspectives, and attitudes." This design allows the researcher to interpret the information based on the sources used to collect the data.

\section{Participant}

The participant in this study was an EFL teacher who has been teaching English for around eight years. She is teaching nine classes of $10^{\text {th }}$ grade students in SMKN 1 Gianyar, Bali.

\section{Instruments}

This study employed interview to collect the data from the participant. Firstly, the researcher conducted an interview by using Google Form to collect the data from the participant about the teacher's challenge in teaching English and the students' problems in learning English. Furthermore, to get more specific information of the teacher's challenge in teaching English and the students' problems in learning English, the writer conducted an interview by using WhatsApp chat. 


\section{FINDINGS \& DISCUSSIONS}

The purpose of the interview was to identify the EFL teacher challenges and EFL learners' problems in classroom. Then, it was continued to identify the teacher solution of the problems exist in teaching English. The result can be seen in Figure 1.

Figure 1. Teacher' Challenges in Teaching English and Students' Challenges in learning English

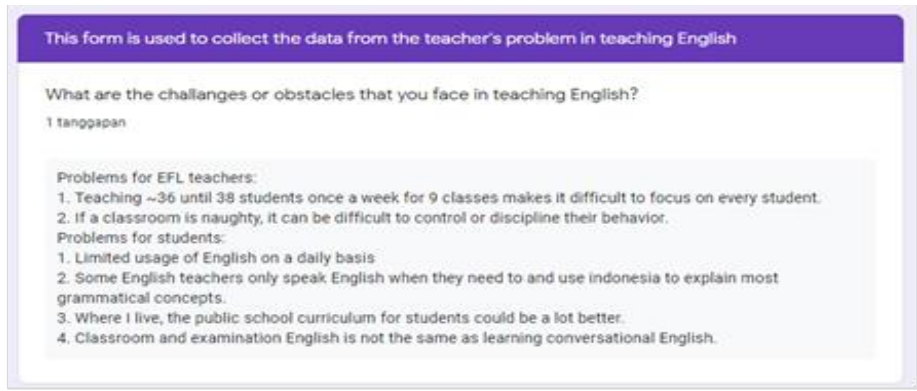

As shown in Figure 1, there were two main problems for the EFL teacher in teaching English and four main problems for the students in the classroom activity. Furthermore, the finding on the teacher solution about teaching to many classes once a week can be seen in Figure 2.

Figure 2. Teacher's Solution for Teaching too many Students

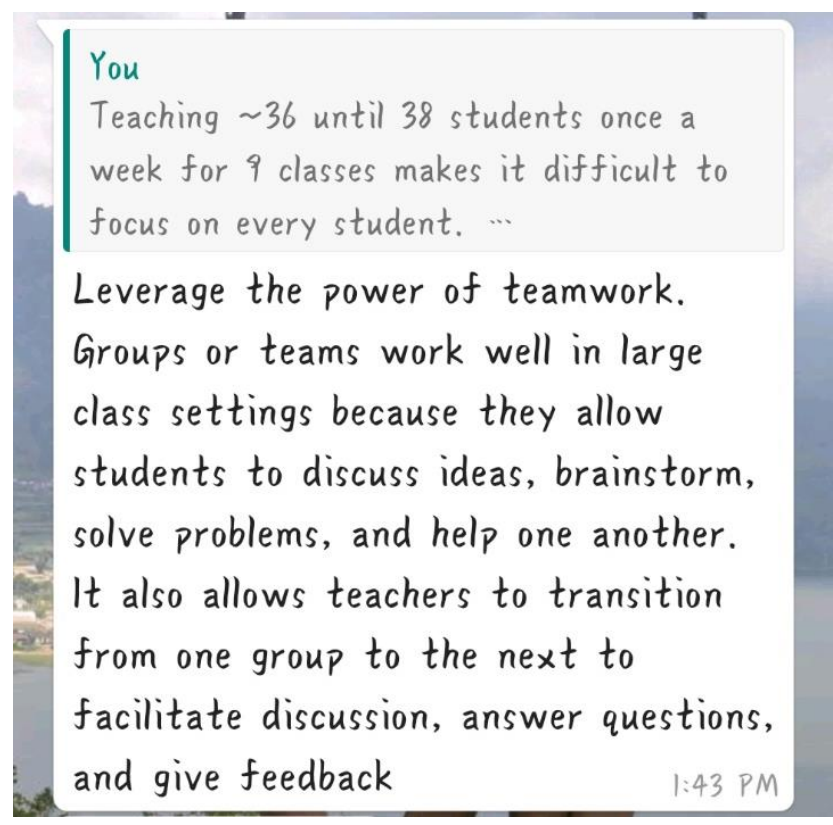

As shown in Figure 2, the teacher said in order to control to many classes once a week and make it easy to focus on every student is by applying the power of teamwork. According to Felder and Brent (2010) as cited in Cornelius-ukpepi et 
al., (2016) define "cooperative learning (CL) as students working in teams on an assignment or project under conditions in which certain criteria are satisfied". Additionally, Duplass (2006) and McKeachie (2007) as cited in Cornelius-ukpepi et al. (2016) state that "cooperative learning is instruction that involves students working in teams to accomplish a common goal, under conditions that include the positive interdependence, individual as well as group accountability, appropriate use of collaborative skills and group processing". This way is very useful in large class settings because it allows the students to discuss ideas, brainstorm, solve problems, and help each other. Every student will take a part in this teamwork and it also allows the teachers to transition from one group to the next to facilitate discussion, answer questions, and give feedback to the students' work.

Besides than what the teacher said about teamwork is the way to teach too many students can solve problems and help one another, the students indirectly improve their collaborative skills and group processing. So, the teacher is not only give a solution how to focus on every student, but she also allows the students to improve another skill. Furthermore, the finding on the teacher solution about students' problem in learning English can be seen in Figure 3.

Figure 3. Teacher's Solution for Teaching too many Students

First of all I had to prepare games to
use in class. When they are playing
the game I played songs in a CD
player. They got so involved with the
athmosphere that they used to forget
that they are playing in a classroom.
Students enjoyed a lot.
so

The result showed that the teacher used games and song to solve the students' problem about the difference between their classroom and examination English and their conversational English. Specifically, the teacher prepares games to use in class. When the students playing the game, the teacher played songs in a CD player. So that the students got involved with the atmosphere that they used to forget that they are playing in a classroom. And as the result, the students enjoyed it a lot.

This problem is very common in every Indonesian school, where the students learn about how to do conversation but in examination English they get a written test. So, this problem is very important for all parties that students do not need a written test, they need how to speak with other by using English. Because when they graduated, they need to be able to speak in public and to do communication with others. Nunan (1995) as cited in Leong \& Ahmadi (2017) state 
that "learning the speaking skill is the most important aspect of learning a second or foreign language and success is measured based on the ability to perform a conversation in the language". This proved that speaking skill examination is more important instead of take a written examination.

\section{CONCLUSIONS}

From the discussion above, the teacher's role in managing the problem that exist when teaching English is very important in order to make the learning instruction successfully. The teacher must also pay attention to students' problem when learning English, because this will be the key of successful learning for students. Furthermore, it is suggested for the teacher to use jigsaw strategy in teaching that will make the students take an important part in teamwork instead of without doing nothing in a group activity.

\section{REFERENCES}

Cornelius-ukpepi, B. U., Aglazor, G., \& Odey, C. O. (2016). Cooperative Learning Strategy as Tool for Classroom Management. June.

Duplass, J. (2006). Middle and High School Teaching: Methods, Standards, and Best Practices. Boston: Houghton Mifflin Company.

Felder, R. M \& Brent, R. (2010). Cooperative Learning. N.C.: N.C. State University Press

Leong, L.-M., \& Ahmadi, S. M. (2017). An Analysis of Factors Influencing Learners' English Speaking Skill. International Journal of Research in English Education, 2(1), 34-41. https://doi.org/10.18869/acadpub.ijree.2.1.34

Marcellino, M. (2008). English Language Teaching in Indonesia: A Continuous Challenge in Education and Cultural Diversity. TEFLIN Journal - $A$ Publication on the Teaching and Learning of English, 19(1), 57-69. https://doi.org/10.15639/teflinjournal.v19i1/57-69

McKeachie, W. J. (2007). Teaching Tips: Strategies, Research, and Theory for College and University Teachers (11th ed.); Houghton Mifflin: Boston, MA, 2002.

Mohammed, M. H. (2018). Challenges of Learning English as A Foreign Language (EFL) By Non-Native Learners. International Journal of Social Science and Economic Research, 03(May), 1397.

Mumary Songbatumis, A. (2017). Challenges in Teaching English Faced by English Teachers at MTsN Taliwang, Indonesia. Journal of Foreign Languange Teaching and Learning, 2(2), 54-67. https://doi.org/10.18196/ftl.2223

Nassaji, H. (2015). Qualitative and descriptive research: Data type versus data analysis. Language Teaching Research, 19(2), 129-132. https://doi.org/10.1177/1362168815572747

Nunan, D. (1995). Language Teaching Methodology: A Textbook for Teachers. NY: Phoenix Ltd., p. 593. Oxford,

Zaim, M. (2017). Implementing Scientific Approach to Teach English at Senior High School in Indonesia. Asian Social Science, 13(2), 33-40. https://doi.org/10.5539/ass.v13n2p33 